${ }^{I}$ University of São Paulo (USP), Brasil

juportenoy@gmail.com

Juliana Portenoy Schlesinger

\title{
DENATURALIZING CULTURE: SAYED KASHUA'S NEWSPAPER COLUMNS ON THE TOPIC OF PREJUDICE
}

On February the $19^{\text {th }} 2009$, Sayed Kashua wrote a column in Israel's leading Haaretz newspaper in which he himself was not directly the target of discrimination. ${ }^{\mathrm{I}}$ Avigdor Lieberman, Israel's newly incumbent Minister of Foreign Affairs, had announced a proposal to make it compulsory for non-Jewish citizens of Israel to declare their loyalty to the Jewish country or else lose their citizenship. The plan and its slogan 'No Loyalty, No Citizenship' caused a huge furor among the Jewish Israeli left, who condemned the proposal as racist and discriminatory. In his column, Sayed Kashua, the I-columnist, ${ }^{2}$ tells his readers that he had been interviewed by a German journalist who had first learnt about 'Israeli Arab citizens' because of Lieberman's plan. Adopting a highly satirical tone, the I-columnist simulates a situation of discrimination in which a neighbor - actually his friend, as Kashua lets his readers know - rang the bell of his apartment and invited him to watch a movie together. " "My neighbor, who's a really great guy, was standing there. He wanted to know if I felt like catching a movie with him. 'Sure,' I said. 'Let me just get rid of this German woman and I'm ready to go.'" Sitting across from the journalist, the I-columnist pretends he is the victim of a discriminatory attack: "Every day it's the same story. He knocks on the door and I open it. He spits on me and then walks away" (Kashua, 2009; also see Schlesinger, 2012).

In his same Haaretz column of August $16^{\text {th }} 2013$, Sayed Kashua describes how the I-columnist and his wife were always waiting for invitations during 
vacations that included their children: "The thing is, all our friends have disappeared. I don't know if it's because we've become a large family - because when you come down to it, who really wants to invite a family of five? Or maybe, in the spirit of the time, they have all turned racist" (Kashua, 2013g).

Sayed Kashua was born in 1975 in the little Arab village of Tira, situated in a region of Israel known as the Triangle, which straddles the Green Line separating the country itself from the occupied Palestinian territories. At the age of I5, Kashua left his hometown after being accepted in a well-known Jewish boarding school in Jerusalem for gifted students, the Israel Arts and Science Academy. Kashua was educated there in Hebrew and all his work is written in the language. He has written three critically acclaimed novels that have subsequently been translated into various languages: Dancing Arabs (2002), Let It Be Morning (2004) and Second Person Singular (2012). In 2004, Kashua won the Prime Minister's Prize for Literature. Sayed Kashua is also screenwriter for the program Avoda Aravit (Arab Labor), now in post-production for its fourth season. Avoda Aravit is one of the top five Israeli comedies of all time and the only show on Israeli television to feature leading Arab characters and dialogue mainly in Arabic. Since 2005, Kashua has written a weekly column in Haaretz, Israel's most important Hebrew newspaper, which also publishes an English version.

Sayed Kashua's work is renowned for its use of unusual humor, sarcasm and self-irony in work that evokes a deeply fragmented society. ${ }^{4}$ In an article entitled "The outsider", the Foreign Policy magazine journalist Debra Kamin (2013) writes that Israel is "a nation plagued by xenophobia and casual racism." In fact, discrimination has been condemned as a huge problem for Israeli society even by the government itself. In one of his columns (Kashua, 20I4a), Sayed Kashua describes a public service commercial broadcast on Israeli television:

We see two children, one black, the other white, having fun in a playground that otherwise looks totally white. The white mother quickly pulls her son away from the black boy [...]. In the same commercial, an Arab woman wearing a head covering gets into a bus with her little daughter. A blonde woman with a nasty look in her eyes spots the Arab woman heading for the empty seat next to her and quickly places her handbag there to prevent her from sitting down [...]. A caption appears on screen: 'Yesterday, they didn't make a place for me, today they're refusing to rent me an apartment.' It ends with the following message on the screen: 'Discrimination is a violation of the law. Together we are fighting it.' Electric guitars that are playing 'Hatikva' get stronger, and then a line from the Israeli national anthem flashes on the screen: 'Our hope is not yet lost.' The sponsor is the Justice Ministry.

Sasson-Levy (2013) discusses just how ethnically fragmented Israeli society is. Ashkenazim - that is, Jews whose families migrated to Israel from Europe and America (singular: Ashkenazi) - are seen within Israel and in the West as representative of the middle and upper classes of Israeli Jewish society. They enjoy the highest socioeconomic ranking, a fact reflected in house price values, family income and educational levels. Their presence in the higher 
echelons of politics, university faculties, the economic elite and the media is likewise much higher in percentage terms than their share of the population. Ethiopian immigrants are discriminated against on both racial and religious grounds since the authenticity of Ethiopian Judaism is still a matter contested by some rabbinical institutions in Israel. Another group suffering discrimination in Israel are immigrants from the former USSR. Yelenevskaya and Fialkova (2004) report that they still feel just as underprivileged as they did when living as a minority in the USSR, but this time as newcomers and as 'Russians' who can be treated unfairly and exploited. At the bottom of the social structure are Israeli Arabs, excluded by powerful social and symbolic boundaries in terms of areas of residence, land ownership, labor market participation, housing and political representation. "A clear hierarchy has been institutionalized in Israeli society in general and in the labor market in particular whereby Ashkenazim are at the top of the socioeconomic ladder, Mizrahim (Asian, Middle Eastern, or North African descent of Jews, so called Oriental Jews) are in the middle, and the Arab citizens of Israel are at the bottom," the authors write (Yelenevskaya \& Fialkova, 2004: 32).

Israeli society is witnessing racist episodes and declarations at a growing rate. "The society is increasingly fraught with racism," says Seth J. Frantzman (20I4), opinion editor of the The Jerusalem Post, who talks about a society which is "[s]tereotyping against citizens who are not considered European-origin 'sabras," referring to the Ashkenazi-origin ideology predominant in the Zionist Movement in the nineteenth century. Frantzman (20I4) argues that this racism is anti-African, anti-Russian, anti-Sephardic (against Jews of Middle Eastern descent), anti-Oriental Jews, and indeed hostile to any group of immigrants who threaten the "demographic composition of the Jewish people." To this list we can add racism aimed at Arab Israelis, a population descended from the I60,000 Palestinians who remained in Israel after the I 948 War and became Israeli citizens. Today they constitute $20 \%$ of the total local population of Muslim, Christian and Druze origin.

The Chief Rabbinate of Israel, a court holding jurisdiction over many aspects of Jewish life in Israel, including personal status issues, including marriage and divorce, burials, conversion to Judaism, and dietary law, has played an increasingly significant role in spreading discrimination and racism in Israel. In 20I0, 39 municipal rabbis called on Jews to avoid renting or selling apartments to Arabs and the ostracizing of those Jews who failed to heed this call. In 2013, the Ashkenazi Chief Rabbi of Israel, ${ }^{5}$ David Lau, was shown on a video telling an audience of young male students that they should not watch European basketball games in public. "Why do you care whether these kushim [a derogatory term used in Hebrew for black people] who are paid in Tel Aviv beat the kushim who are paid in Greece?" (Haaretz, Jul. 30 2013). Similar statements were made by the Sephardic Chief Rabbi, Yitzhak Yosef, who accused 
the Treasury of financing "kushim in basketball" at the expense of synagogues and mikvehs. ${ }^{6}$

Open manifestations of discrimination are easily found. In December 20I I, a choir of Christians was singing Christmas songs in the entrance of an open mall next to the Old City of Jerusalem when a group of young teenagers dressed as orthodox Jews jumped on them and shouted "get out of here." In 20I2, several dozen Israeli Jewish teenagers - some reports state as many as 50 - assaulted four Palestinian youths in the center of Jerusalem, an attack that the Jerusalem police labeled as an attempted 'lynching.' The young people shouted "death to Arabs" as they chased down and beat the Israeli Arabs (Hasson, 20I 2). That same year, hundreds of supporters of Beitar Jerusalem Football Club entered Jerusalem's Malha Mall, hurling racial abuse at Arab workers and customers, and chanting anti-Arab slogans (Rosenberg, 2012). A year later, they protested against the team's decision to hire two Muslim players (Prusher, 2013). Kashua also blames the media for the growing intolerance in Israeli society. In one column (Kashua, 20I4e), the I-columnist reports that he was watching a Channel I news report showing

a I8-year-old Arab from Taibeh who had been sentenced to life imprisonment (who) reenacted for the police, at length, how he had planted a bomb on a bus in Bat Yam. The anchorwoman took a long, meaningful breath in the wake of the report before proceeding to the next item: the death of the legendary fighter Meir Har-Zion. ${ }^{8}$ Har-Zion was a reconnaissance man, Har-Zion loved the land, Har-Zion fought for the homeland. Occasionally he committed murder, occasionally he blew up buildings with civilians inside, occasionally he was let off instead of being tried, but they didn't say that on the news - because there are some things you don't say.

"Is some killing more humane than other kinds?" asks the I-columnist in another article (Kashua, 2013h) where he argues that Israeli society discriminates between the country's population according to ethnic or religious background.

During an intensification of violent physical attacks on the Arab population in Israel, Kashua wrote the column "The warning Sayed Kashua didn't give his daughter" (Kashua, 20I3c). Here the I-columnist recounts how he had advised his daughter on how to protect herself before she embarked on a trip.

I wanted to tell her that we're experiencing a difficult period, to remind her of the woman who was beaten up at the light rail station in Jerusalem because she's an Arab, to tell her about the gang of young men who mercilessly beat an Arab sanitation worker from Jaffa. I wanted to make sure that she doesn't get confused, that she knows that no matter how she dresses, speaks, what music she listens to and which school she attends' ${ }^{9}$, that she still knows she's different, and that she can never be sure.

Much of the self-deprecating humor involves situations in which Arabs pretend to be Jews. Sayed Kashua has written a lot about Jewish ways of dressing and speaking, a Jewish kind of music. In his novels, as well as his columns 
and the Arab Labor sitcom, Sayed Kashua's characters are always keen to look like Jews as a way to avert prejudice. As writes in one column:

As we approached the security guard at the entrance to the car park, I turned up 88FM [a Jewish radio station], as I always do, and put on my biggest smile. "Hello," said the guard, peering in the car window. "Everything okay?" "Everything's good," I replied (...). "Go right ahead," said the guard. "Yes!" shouted my son as we started to move forward, because again we'd won our little game and the guard hadn't asked to look inside the glove compartment or the trunk. "We did it!," exulted my son (Kashua, 2012a).

Doubt and uncertainty are a hallmark of the I-columnist's Israeli Arab speech when it comes to the future of the Arab population in the State of Israel. In one column (Kashua, 20I4f) in which the I-columnist declares he is in favor of a boycott against Israel, ${ }^{\text {to }}$ he states:

Believe it or not, ladies and gentlemen, I am in favor of the boycott, because, despite the sometimes unforgivable injustices done and the fact that the state is liable not to consider me a citizen, and even though it is threatening to get rid of me and my family by means of plans of one kind and another ${ }^{11}$ - I am in favor of the boycott because I love that screwed-up, dumb country and wish it only well.

The I-of the-columnist's appreciative comment concerning his feeling towards Israel is found in the 2013 Index of Arab-Jewish Relations in Israel (not yet published) conducted by Professor Sammy Smooha (see Solomon, 20I4). ${ }^{\text {I2 }}$ Smooha also perceived a weakening of the tendency for Israeli Arab's to express a negative opinion of Israel $^{13}$ along with an improvement in Arab perceptions of the Jewish state. In 20I3, 64 percent thought that Israel was a good place to live, compared to 59 percent the year before. Already in the 2012 research, Smooha noticed a growing desire among Israeli Arabs for greater integration into Israeli society (Smooha, 20I2). As for the Jewish public, 74 percent of Israeli Jews in 2013 recognized the right of Arabs to live as a minority in Israel with full civil rights, compared to 75 percent in 20I2. According to Smooha on the findings of the 2013 Index, "contrary to popular belief, Jews' opinions about Israeli Arabs are not undergoing radicalization but demonstrate longterm stability" (Solomon, 20I4).Despite this comparative statement, the 2013 study found that a very high percentage of Israeli Arabs (7 I percent) still fear serious harm to their rights.

Over the last couple of years, Sayed Kashua has virtually stopped writing about the prejudice from his own Israeli Muslim community against the Israeli Jewish population, and has turned to express his concern about the prejudice shown by Jews against Arabs in Israel. Self-criticism has always been a remark of Sayed Kashua's work so this shift effectively points to a change in the columnist's perception of his own society, what he calls the "spirit of the time" (Kashua, 20I3g). 
Plenty of Sayed Kashua's columns report this fear of being considered suspicious by Israeli Jewish society. In the article "What exactly is this thing the Jews call 'Arab Mentality'?” (Kashua, 2013a), the I-of the-columnist reports this fear very clearly.

I passed through the checkpoint slowly, careful not to make any movement that might be deemed suspicious, and without unnecessary acceleration, trying to intimate that I'm still here, if anyone there is having second thoughts.

The same feeling appears in another column (Kashua, 2013i):

I saw a green, new-looking knapsack lying on the pavement between two cars parked opposite mine. I looked around in the hope of seeing someone who was looking for it. [...] But in vain. [...] Should I ignore it? After all, it wasn't a suspicious object [...]. But what if a security guard should appear, notice the knapsack and ask, "Yours?" "No," I would reply, and he wouldn't be able to understand how I could stand so close to an abandoned bag and not feel the need to report it. Two questions from the guard and he would realize that I am an Arab, and I might find myself the main suspect. And if, heaven forbid, it were to turn out that [...] (it) really was booby-trapped, that would be the end for me. I would probably be released in 30 years and the radio announcer would say I was a terrorist murderer.

Rekhess (20I4: I9I) explains: “The feeling of distrust, suspicious, and fear on both sides (Jewish and Arab) heightened the mutual tension following the October 2000" events [referring to the beginning of the Second Intifada] . Despite the fact that Israeli Arabs and Palestinians have had different allegiances in the wars in which Israel has been involved since its declaration of independence in 1948, the Israeli Arabs are considered part of the larger hostile Palestinian community and all events in the wider context of the Israeli-Palestinian conflict influence Jewish-Arab relations in Israel. In the political sphere, Israeli Arabs also react to these wider events, as in the case of the publication of the Future Vision Document ${ }^{\mathrm{I4}}$ in 2006. Although an insignificant number of Israeli-Arab citizens have been involved in violent events against the Jewish population during the First and also the Second Intifada, the very tense situation which saw an escalation in Palestinian terror attacks and the rise of Hamas and suicide bombings led to a perceptibly growing fear of the Arab population among Jews. Many consider this fear to be the main cause of discrimination. Others argue that this discrimination is connected to the very nature of the State of Israel, which tries to combine a Jewish and democratic State. A third possible source for the discrimination against Arabs in Israel is the growth of the Israeli Arab population, seen as a threat to the State's Jewish majority.

Although Israel's declaration of independence grants all citizens individual political, economic, legal and religious rights assured by the State, including freedom of speech and political organization, the right to vote and security, the fact that Jewish interests are embedded in the concept of security means that the state simultaneously reinforces its Jewish identity and emphasizes the Jew- 
ish population's separateness from non-Jews inside the country (Rouhana, I997). Arabs citizens claim that Israel, as a Jewish state, fails to uphold its democratic values by neglecting to provide them with the same advantages extended to Jews, a situation reflected in the unequal allocation of socioeconomic resources, the laws of citizenship based on ethnicity, their lack of cultural autonomy, and the absence of any rights as a homeland minority. Ghanem (200I: 9) believes that "Israel has a maximum ethnic component and a limited democratic one". The author adds that Israel did not want - nor has it made any attempt - to integrate or absorb the Arab population into the Jewish community.

Discrimination is also seen in the field of language. A non-equal status is attributed to Hebrew and Arabic, though they are both official languages in Israel. In an article published in Haaretz, Chassia Chomsky Porat and Azar Dakwar (20I4) discuss the prejudice expressed in Israeli society against literary works written in Arabic by Jewish and non-Jewish authors alike. The authors write: "authors who write in Arabic, both Arabs and Jews, are in effect excluded from the monetary prize [referring to the Sapir Prize ${ }^{\mathrm{I}}$ ] and public exposure." They add: "Arabic literature in Israel would receive exposure to and recognition by the non-Arabic reading public. It would also provide writers with an incentive to write works in Arabic - books that certainly enrich the cultural life of the society in Israel in general." They also recommend the translation of works written in Hebrew into Arabic. ${ }^{16}$

Despite the considerable disparity between Arabs and Jews in Israel, many Israeli Jews argue that Israeli Arab citizens should be thankful that they are living in Israel rather than an Arab country. As Kashua puts it:

...the formula imposed by Israel, according to which we have to be thankful that we are not in Syria and not in Cairo. True, the average Israeli will admit: You are not equal, but you still don't have anything to worry about. The fact is you're not being slaughtered in the streets. As long as the killing in Syria and Egypt continues, it's okay for Beitar Jerusalem fans to demand racial purity (Kashua, 20г3a).

In another column, the I-columnist, trying to reassure his wife when she mentions their children's fears of sleeping alone, tells her that their security is guaranteed so long as they stay in Israel: "As long as it's within the I948 lines [referring to the border defined in the I948 War], my children can sleep wherever they want" (Kashua, 20I4C), satirically assuming that their Israeli citizenship gives them protection.

Generalization is another form of discrimination that appears in Sayed Kashua's columns. Listening to a radio news report on the release of terrorists, the I-columnist writes:

What kind of person would not be appalled by a despicable murder, not to mention by celebration of the release of those human beasts involved in bloodthirsty barbarism? (...) So why the hell did his [the commentator's] comments strike me as so militant and provocative that I preferred to turn off the radio? Maybe because 
of the implicit generalization that these terrorist murderers were Arabs. That Arabs are the ones who are sick in the head, and only Arabs are capable of dancing on blood and of seeing the prisoners' release as a sign of victory (Kashua, 20I3h).

In a column already mentioned earlier, "What exactly is this thing the Jews call 'Arab mentality'?" (Kashua 2013a), the I-columnist questions the intention to generalize and naturalize Arab people's behavior.

$[\ldots]$ it is all a question of mentality, the Israeli will say, for, after all, every halfwit knows that the Arab will forever return to his village; it's part of his culture. Really? [...] Is it the Arab culture to always live near one's parents? Isn't that a culture that is coerced?

Israeli Arabs have been intimidated by the rise of the Jewish right over the last few years. Rekhess (2014: I92) explains: "[In 2009] Anti-Arab legislation introduced in the Knesset was a major factor in the Arabs' increased sense of estrangement and fear and also reflected Jews' distrust of them". Discriminatory bills include the Citizenship and Entry into Israel Law, ${ }^{17}$ the Loyalty Oath (discussed by Sayed Kashua in the aforementioned column 'No Loyalty, No Citizenship'), the Nakba Bill, ${ }^{18}$ the Admission Committees Law, ${ }^{19}$ and the initiative currently under discussion: 'Israel: the Nation State of the Jewish People.' ${ }^{20}$ In 2010, Sawsan Rahami declared the Eighteenth Knesset (Parliament) the most racist since the establishment of Israel in 1948 , when the number of racist bills aimed at depriving Arab citizens of their rights had reached a new high (Rahami, 20I0). Twenty-one such draft bills had been submitted to the Knesset members for consideration (compared to eleven in 2008). According to Rahami, all of these laws sought to demote the status of Arab citizens and reduce their rights, while posing a continual threat to the legitimacy of their presence in Israel. At the start of 20I4, the Igth Knesset approved a law proposing to distinguish between Muslim and Christian Arab citizens. Critics blame the law as an attempt to 'divide' the Israeli Arab population (Lis, 20I4). Sayed Kashua (20I4d) wrote about the 'Governance Law'21 in his Haaretz column.

Most of these bills have not been passed in the Knesset or are still being discussed. Nevertheless, their consequence is a "growing mutual alienation of Arabs and Jews in Israel" (Rekhess, 2014: 190). The bills erode the already fragile relationship between the populations, increase Arab frustration and rage, and, at the same time, augment Jewish fears and concerns about the loyalty of the Arab population to the Jewish State.

Sayed Kashua the columnist dreams of Israel becoming a country for all its citizens, although nowadays the government is doing the exact opposite: "it is trampling it, reasserting that Jews are Jews and Arabs are Arabs" (Kashua, 20I4d). Today still, when registering for an Israeli ID Card, people have to fill out a form indicating their 'nationality' (where, for Arabs, the single option is 'Arab'). Applicants from minority populations also have to indicate their grandfather's name. 
Ironically, Israeli Arabs - as Israeli citizens - often experience prejudice from the outside world as they can been seen as partners of the Israeli government: "[...] since Arabs have Israeli passports, they can be seen as 'collaborators' with regards to a boycott seen in American university against Israel due to the occupation of Palestinian territories" (Kashua, 20I4f), not to mention the perceived dual loyalty of Israeli Arabs families who stayed in the Israeli territory after the 1948 war and received Israeli citizenship in contrast to those who did not.

A recent Sayed Kashua column (Kashua, 20I3i) expresses this conflicting identity of the Israeli Arab and how Israeli citizenship can be seen as a betrayal by some while for others it may mean nothing. After realizing that when moving to the United States for a sabbatical year the I-columnist family would be seen as Arab Muslim, Kashua declares that “it won't help to start explaining that, yes, we really are Arabs, but we have Israeli citizenship. No one there will give two hoots about our passport. If our Israeli citizenship is meaningless over here (in Israel), is it going to prove useful in the United States of America? Not a chance!" - suggesting that the Israeli Arab would always be caught in a trap.

In the column mentioned earlier in which the I-columnist describes the public service commercial against prejudice, shown on Israel television and sponsored by the Justice Ministry, Kashua asks:

Really? Discrimination is a violation of the law and this is how the Justice Ministry is fighting it? Are the apartment owners, real-estate agents and builders who don't sell or rent apartments to Arabs, Ethiopians or Russians punished for perpetrating discrimination? Are the municipal rabbis who explicitly call for discrimination against Arabs removed from their posts? And where is the law when it comes to admission committees for communities, family unification, allocation of resources, the establishment of new towns? (Kashua, 2014a)

In the columnist's view, discriminatory laws and the failure to punish discrimination go beyond the legal sphere and implicate the most day-to-day interactions between people. This is spread in the difference in language status, in the business sphere and in the media. But still Israeli Arabs, as well as facing discrimination within their own country, are forced to deal with the prejudice directed against them by people from others countries, who think of them as Israeli citizens and thus Jewish themselves, since they have Israeli citizenship, or as citizens with a supposed dual loyalty, since they may have close relatives who did not receive Israeli citizenship. ${ }^{22}$ And still these Arabs must be thankful to Israel because they have their rights assured by the state despite the social situation of discrimination in which they find themselves.

In fact it is notable that Kashua has almost ceased writing about his own prejudices in the last few years. A growing sense of detachment from Israeli society can be perceived in his columns. Kashua himself told me that it is getting harder and harder to laugh in Israel. Living abroad has started to occupy his mind (Kashua, 2013d): 
I must help my children understand that Israel is not the end of the world - that if, God forbid, they don't succeed there and they feel ostracized, different, suspect, or when the reality blows up in their faces, they'll know that there are other options. It's true that they'll be different, but in a different way. They'll be immigrants, and maybe they'll have an accent, and they'll feel a little strange. But they'll be strangers in a strange land, and not in their homeland. ${ }^{23}$

In the column "Price tag: Sayed Kashua will do anything for a good night's sleep" (Kashua, 20I2b), the I-columnist recounts an episode in which he and his wife were in a mattress store when the salesman revealed a speech impediment.

"Pleased to meet you," he said, still smiling, and revealing a slight speech problem. He spoke very slowly, emphasized each letter and nodded his head after every word. "Yo...u kn...ow ab...out th..is matt...ress?" he asked, naming a brand that every child in Israel is familiar with. 'Y...e...s,' I replied in the same vein out of politeness, so he wouldn't think, God forbid, that my fast speech was meant to mock him, "We've he...ard of th...at matt...ress." After some minutes, the salesman went away to answer the cell phone that was ringing in his pants pocket. "Hello," he answered with a speed that left me and my wife amazed. "Moshe, I'll get back to you in 5 minutes. Yalla, bye," he hung up. "So wh...ere we...re we?" he continued slowly, while nodding. I looked at my wife, who looked back at me. "Ah, yes, th...e matt...ress." "Listen," I said to him at top speed. "We know what this damned mattress is, do you understand?" "Yes," he answered in panic. "But why are you angry?" Because we may be Arabs," I answered irritably, "but we aren't idiots."

This salesman apologizes and says "I didn't intend to insult you," but the I-columnist takes him to be a "racist idiot." Not long after this article, in the column "Sayed Kashua: Racist, but polite" (Kashua, 20г3e), the I-columnist puts himself in the same place of this "racist idiot" when he himself speaks deliberately slowly to a stranger. He recognizes his own prejudices: "Okay, I'm a racist. Last Friday, I realized that I'm both an idiot and a racist."

The column tells of a picnic organized to celebrate the birthday of a boy from his son's class. The boy's mother compliments the I-columnist for his son's politeness. "I've always liked to get compliments from Ashkenazim," recognized the I-columnist. As he is about to leave his son at the party, having arranged to pick him up later, he sees Amir, another of his son's friend, whose parents are Ethiopian.

"Shalom," I found myself saying with a broad smile to Amir's parents, whom I had never met. I introduced myself and mentioned my son's name. [...] "They are very, very close friends," I said, speaking slowly, emphasizing the letters, almost using sign language. I couldn't control myself, and I couldn't wipe the dumb smile off my face. "Ex-treme-ly close." [...] "Your son is lovely," I told the two, and they smiled with pride. "He's so polite," I added.

The I-columnist is self-consciousness about the fact that he felt a need to compliment Amir for his politeness but did not feel the same about Tomer, whose mother is Ashkenazi. 
Did I not expect a black kid to be polite? Damn! They must have been insulted, I thought to myself. What have I done? Now they'll probably think I'm a racist, trying to hide behind the compliments I'm heaping on their son. But that's not the case - he really is a lovely boy, and I love him, even though he's an Ethiopian. Damn! Why "even though"? What the hell is happening to me?

The I-columnist recognizes that there are preconceptions one cannot avoid and that in practice these become prejudiced behaviors. In this case, the prejudice happens to be directed against black people.

At this same party, the I-columnist is introduced to a woman who, as soon as she realizes that she is having a conversation with an Arab, says: "Extreme-ly pleased."

It seems that the columnist deals with prejudice and racism in two different ways. Where the discrimination is shown by Israeli Jewish society against Israeli Arabs, the fear of the other is highlighted, a fear mainly related to physical violence. On the other hand, the I-columnist is able to consider discrimination as a point of view and almost a 'natural' behavior in dealing with the different and the other.

In the column "Sayed Kashua racially profiles his own kids and gets a shock: Ahead of his sabbatical in Chicago, the Haaretz columnist concludes he is both a non-white and a racist" (Kashua, 20I3h), the columnist realizes that racism is all a question of one's point of view.

I am nothing but a backward racist. This is an insight that waylays me every so often and always finds me totally unprepared - because deep down I am convinced that I am an enlightened liberal and in no way driven by stereotypes and prejudices.

This I-columnist usually sees enlightened liberal people as archetypes of non-prejudiced individuals. Translated as 'Ashkenazim,' these enlightened folk are the ones who built the modern State of Israel and have been the most powerful section of Israeli society ever since.

The desire to be white can be found in a large number of Sayed Kashua's articles. Looking for a school where his children can study during his sabbatical year in the United States, the 'I-of-the-columnist' concludes: “...schools [in Chicago] with the highest proportion of 'white students' must be the most highly regarded institutions" (Kashua, 2013h).

The desire to be Ashkenazi is also often found in his columns: "I've decided that I am Ashkenazi" (Kashua, 20I3h), I-columnist informs the reader in relation to a form that he was meant to fill out. In the column "Sayed Kashua's youngest has an Ashkenazi condition" (Kashua, 20I4f), the I-columnist rejoices when he learns that his son has celiac disease, an illness common among Ashkenazi Jews.

I'm a little ashamed to admit it, but I smiled. I felt that celiac, which I'd never even known existed, was a much more fitting illness for our family rather than 
thalassemia, which is a disease common among Mizrahim and with quite similar symptoms.

In the column "Sayed Kashua is surprised to discover he's white" (Kashua, $20 \mathrm{I} 4 \mathrm{~g}$ ), the I-columnist tells the story of his family applying to obtain a visa for the USA. Asked to fill in the forms, he writes that:

Going through the visa forms beforehand, I had been thrown by the 'race' rubric. I looked for Arab but could find no such category. There was white, black, Hispanic and Asiatic, but no Arab. I looked on the Internet to find out what we are and discovered that in the United States, people coming from the Middle East or North Africa are considered whites. That really surprised me, because I never considered myself white. I now remember the moment when I checked the 'white' box on the forms: I grinned with a leer and knew that I was going to be a racist - and how I was going to be a racist! Especially after 40 years ${ }^{24}$ of experience with this.

Although the columnist talks about 'de-generalizing' and denaturalizing mentalities, behavior and pre-judgment, he confesses his own desire for revenge. As soon as he no longer perceives himself as the victim of prejudice, all he can see is himself as the tormentor, as though a relation between two parties is always going to be based on exploitation: there will always be a persecutor and there will always be someone who is oppressed.

This turning point in Sayed Kashua's work - where in the past he used irony and self-deprecating humor to express prejudice, nowadays he talks directly about discrimination - can be seen as a more mature way of observing his society, a view that denaturalizes culture ${ }^{25}$ and sees it as a coerced creation of the strongest side. Sayed Kashua is not ashamed to speak out loud against the prejudice directed at Arabs in Israeli society. At the same time, neither is he too ashamed to admit that this character himself has preconceptions or that his fervent wish is to be Ashkenazi.

In "Sayed Kashua's pride and prejudice" (Kashua, 201 2a), the I-columnist writes about his daughter telling him of her humiliation one afternoon when she was playing and accidentally bumped into a boy from her after-school class. The boy had exclaimed: "Oh, gross, the Arab touched me!" The I-columnist himself felt ashamed and had no words to comfort his daughter. Would he be able to tell her that he would say the same if he was the boy? 
Juliana Portenoy Schlesinger is a postdoctoral researcher at the University of São Paulo (USP) with a scholarship from FAPESP. She received her PhD in Hebrew Literature from USP with a thesis on Sayed Kashua's novel Aravim Rokdim, which focuses on the identity conflicts experienced by Israeli Arabs. She completed her master's degree in Anthropology at the Hebrew University of Jerusalem and holds bachelor's degrees in Social Sciences (USP) and Journalism (Pontifical Catholic University of São Paulo/PUC-SP). 


\section{ENDNOTES}

I The categories of discrimination and prejudice have been subject to much debate. Kohler-Haussmann (20I I) proposes that the sociological study of discrimination can be divided into two lines of inquiries: one that sees discrimination as a social phenomenon to be explained, and one that takes discrimination as an explanation for other observed social phenomenon (Kohler-Haussmann, 20II). On the Israeli context, Kimmerling (2008), for instance, argues that it is through torture, detention without trial, expulsions and collective punishment against Arabs as a collective group that Israel continues to practice 'ethnic discrimination.' Kashua (personal communication, Jerusalem, 2009) says that discrimination in Israel involves the categorization of its people irrespective of their own self-categorization. Yiftachel (2000) sees discrimination in Israel as an intrinsic part of its 'ethnodemocracy.' In this article, I approach discrimination as a social process.

2 Simon (20I I) proposes the expression 'eu do cronista,' the 'I-columnist' to detach the column's author from the situations described in the texts. In this article, I use the term with the same meaning, even when the columnist is identified as Sayed Kashua. In a recent work (Schlesinger, 20 I 2) I also discuss the 'new literary paradigms' and the tools used to study newspaper columns as literary texts.

3 Though originally written in Hebrew, all of Sayed Kashua's columns cited here have been published in the English version of Haaretz.

4 For more on Sayed Kashua's sense of humor, see Schlesinger, 2009.

5 The Chief Rabbinate of Israel is the supreme Jewish legal and spiritual authority on matters concerning the Jewish people in Israel. The institution consists of two Chief Rabbis: an Ashkenazi rabbi, who represents Eastern European Jews, and a Sephardic rabbi, who represents Jews coming from the Arab countries, Portugal and Spain.

6 Ritual bathing pools intended for the Jewish rite of purification.

7 Witnessed by the author in Jerusalem, December 20 I I. 
8 Meir Har-Zion (I934-20I4) was a member of the Israeli military elite.

9 The Israeli public education system is organized into three levels: 'Jewish General schools,' 'Religious-Jewish schools' and 'Arab schools.' In the Jewish sector, the language of instruction is Hebrew, while in the Arab sector Arabic is used. The three sectors are governed and pedagogically administered by the Israeli Ministry of Education. Jewish schools are considered better than their Arab equivalents since the number of teachers per student is higher and they are better equipped. Students of Arab origin can be found studying at Jewish schools, as in the case of the daughter of I-columnist. In I 997 bilingual and binational HebrewArabic schools were established in Israel (Schlesinger, 20I I).

Io The boycott of Israeli products has mostly been evident among US consumers and is designed to pressurize Israel into leaving the Palestinian territories. In this column, the I-columnist defends the action since it is "necessary to compel Israel's leaders to get their act together and strive for an agreement that will put an end to the occupation and the discrimination" (Kashua, 20I4f).

I I In 2004, Avigdor Lieberman launched the 'Populated-Area Exchange Plan.' This plan proposed the transfer of part of Israel's Arab population to a newly created Palestinian state in return for evacuation of Israeli settlements in the West Bank. In general, Israeli Arabs are opposed to the plan, condemning it as racist. The Israeli left opposes the plan too and legal experts have cast doubt on its legality under Israeli and international law. See <http://www.haaretz.com/ news/diplomacy-defense/lieberman-presents-plans-forpopulation-exchange-at-un-I.3I6I97>.

I 2 To gather data for the Index, Smooha and other researchers spoke to 700 Arabs and 700 Jews across the country. The Index was launched in 2003 and is published annually.

I3 Smooha believes the weakening of the tendency for Israeli Arabs to have a negative opinion of the country might have been due to the ongoing peace talks at the time and the release of Palestinian prisoners. He also suggests that it reflects Arab disappointment with the Arab Spring, which demonstrated the benefits of living in Israel. 
I4 The Future Vision Document was launched by the Arab Israeli intellectual elite. The Israeli Arab and Jewish elites read it in two different ways. The former believed that the document declared the right of Jews to govern their own statehood and their own desire to remain in the Jewish state, but they condemned their low status as citizens and the lack of laws safeguarding their rights as a collective political, cultural and social group. Meanwhile, the Jewish elite believed that the document demanded a change to the Jewish character of the country. "A sense that Israeli Arabs are being discriminated against may have been the incentive for writing this document, but let us not confuse this with the demands that are being made. Discrimination is a subject that needs to be dealt with, also for the sake of the Jewish and democratic character of the state. But to demand a change in the Jewish character of the country is something else entirely. That issue is not up for discussion" (Schiff, 2007).

I5 Sayed Kashua was among the authors shortlisted for the Sapir Prize in 20I I. As mentioned earlier, Kashua won the Prime Minister's Prize for Literature for Hebrew writers in 2004.

I6 In Israel, languages are important symbols of loyalties and were a controversial subject even before the establishment of the Israeli State. Hebrew became a major component of Zionist ideology and Jewish nationalism in Israel, as well as in the diaspora, and Jewish identity has become inextricably bound up with the language, just as Arabic is a major source of identity and a cultural framework for Palestinians and Israeli Arabs. Arabic and Hebrew are both official languages in Israel, although Hebrew has acquired a privileged status among Israeli Arab citizens too (Schlesinger, 20I5).

I7 The 'Citizenship and Entry into Israel Law' places restrictions on Palestinians from the West Bank and Gaza who may be Israeli citizens (Rekhness, 20I4).

I 8 The 'Nakba Bill' prohibits groups financed by the state from sponsoring activities related to remembering Nakba Day ('Day of the Catastrophe,' which annually commemorates the displacement of Palestinians before and after Israel's declaration of independence). See Rekhness, 2014. 
I9 The 'Admission Committees Law' establishes a system through which admissions committees accept or reject candidates requesting to settle in areas of the Neguev Desert and Galilee with fewer than 400 families. These committees cannot refuse candidates on the basis of race, religion, nationality or physical disability (Rekhness, 20I4).

20 This initiative was abandoned in June 2013. Its proposals included dropping Arabic as an official language, requiring the state to devote resources specifically towards the establishment of Jewish settlements in the territories occupied in the 1967 War, and instituting Jewish law as the basis for Israel's legal system (Rekhness, 20I4).

2 I The Governance Law implies that Israeli parties with less than 4 seats would be out. In this case, the Arab parties would have to merge to survive.

22 In the United States, Israeli Arabs are still seen to be just like any other Arabs and their Israeli citizenship fails to protect them from the suspicions directed towards Arabs (Kashua, 2013i).

23 Sayed Kashua wrote a column in which he declares he will leave Jerusalem and would never come back (Kashua, 20I4h).

24 Sayed Kashua was himself 40 years old in 2014.

25 Lughod (I99I) argues that power is embedded in every relation with the other and sees culture as a place of inconsistency, empowerment and judgment.

\section{BIBLIOGRAPHY}

Frantzman, Seth J. (20I4). Israel's Uncomfortable History of Racist Engineering. Forward, Apr. 2I. Available at <http:// forward.com/articles/1967I9/israel-s-uncomfortable-historyof-racist-enginee/>. Accessed II/29/20I5.

Ghanem, As'ad. (200I). The Palestinian-Arab minority in Israel, I 948-2000: a political study. Albany: State University of New York Press.

Haaretz. (20I3, Jul. 30). Newly elected chief rabbi slammed for 'racist' jibe. Available at <http://www.haaretz.com/jewishworld/jewish-world-news/I.538848>. Accessed I I/29/20I5. 
Hasson, Nir Hasson. (2012). In suspected Jerusalem lynch, dozens of Jewish youths attack 3 Palestinians. Haaretz, Aug. I7. Available at <http://www.haaretz.com/news/national/in-suspected-jerusalem-lynch-dozens-of-jewishyouths-attack-3-palestinians-I.459002>. Accessed I I/29 /20I5.

Kamim, Debra. (2013). The outsider. Foreign Policy, Apr. I 2. Available at <http://foreignpolicy.com/2013/04/I 2/the-outsider/>. Accessed I I/29/20I5.

Kashua, Sayed. (2009). New species. Haaretz, Feb. I9. Available at <http://www.haaretz.com/new-species-I.270530>. Accessed I I/29/20I5.

Kashua, Sayed. (2012a). Sayed Kashua's pride and prejudice. Haaretz, Jul. 5. Available at <http://www.haaretz.com/weekend/weekend/sayed-kashua-s-pride-and-prejudice-I.449I02>. Accessed I I/29/20I5.

Kashua, Sayed. (2012b). Price tag: Sayed Kashua will do anything for a good night's sleep. Haaretz, Nov. 22. Available at <http://www.haaretz.com/weekend/weekend/price-tagsayed-kashua-will-do-anything-for-a-good-night-s-sleep. premium-I.479856 $\geq$. Accessed I I/29/20I5.

Kashua, Sayed. (2013a). What exactly is this thing the Jews call 'Arab Mentality'?. Haaretz, Feb. 9. Available at <http:// www.haaretz.com/weekend/weekend/what-exactly-is-thisthing-the-jews-call-arab-mentality.premium-I.502039>. Accessed II/29/20I5.

Kashua, Sayed. (2013b). The warning Sayed Kashua didn't give his daughter. Haaretz, Mar. 7. Available at <http://www. haaretz.com/blogs/sayed-kashua/the-warning-sayed-kashua-didn-t-give-his-daughter.premium-I.507925>. Accessed I I $29 / 20$ I 5 .

Kashua, Sayed. (20I3c). Sayed Kashua's quest for another homeland. Haaretz, Mar.i4. Available at <http://www. haaretz.com/weekend/sayed-kashua/sayed-kashua-squest-for-another-homeland.premium-I.509475>. Accessed I I $/ 29 / 20$ I 5 .

Kashua, Sayed. (20г3e). Sayed Kashua: Racist, but polite. Haaretz, Jun. 6. Available at <http://www.haaretz.com/ weekend/weekend/.premium-I.528I55>. Accessed I I/29/ $20 I 5$. 
Kashua, Sayed. (2013f). Sayed Kashua's youngest has an Ashkenazi condition. Haaretz, Jun. 2I . Available at <http:// www.haaretz.com/weekend/weekend/.premium-I.53098I >. Accessed II/29/20I5.

Kashua, Sayed. (2013g). Sayed Kashua's kids spend a hot summer evening beyond the Green Line. Haaretz, Aug. I6. Available at <http://www.haaretz.com/weekend/weekend/. premium-I.54I684>. Accessed I I/29/20I5.

Kashua, Sayed. (2013h). Sayed Kashua reports a suspicious bag, will he end up the suspect? Haaretz, Nov. 7. Available at <http://www.haaretz.com/weekend/weekend/.premium-I.556752>. Accessed I I/29/20I5.

Kashua, Sayed. (2013i). Sayed Kashua racially profiles his own kids and gets a shock. Haaretz, Nov. I4. Available at <http:// www.haaretz.com/misc/iphone-article/.premium-I.557962>. Accessed II/29/20I5.

Kashua, Sayed. (2014a). Sayed Kashua's children hear only one Zionist story. Haaretz, Feb. 6. Available at <http:// www.haaretz.com/weekend/weekend/I.572867>. Accessed I I $/ 29 / 20$ I5.

Kashua, Sayed. (20I4b). Knesset passes bill distinguishing between Muslim and Christian Arabs. Haaretz, Feb. 25. Available at <http://www.haaretz.com/news/national/.premium-I.576247>. Accessed II/29/20I5.

Kashua, Sayed. (20I4c). Sayed Kashua's kids are afraid to sleep alone. Haaretz, Mar. I. Available at <http://www. haaretz.com/weekend/weekend/.premium-I.576823>. Accessed II/29/20I5.

Kashua, Sayed. (20I4d). Sayed Kashua's occupation? Don't get him started. Haaretz, Mar. I5. Available at <http://www. haaretz.com/news/national/.premium-I.57966I $>$. Accessed I I $29 / 20$ I 5 .

Kashua, Sayed. (2014e). Sayed Kashua's Mideast conflict will not be played out over a football match. Haaretz, Mar. 22. Available at <http://www.haaretz.com/news/national/. premium-I.58097 I\#>. Accessed I I/29/20I5.

Kashua, Sayed. (2014f). Boycotts and bagels: Sayed Kashua goes Yonkers. Haaretz, Apr. 5. Available at <http://www. haaretz.com/weekend/weekend/.premium-I.583664>. Accessed II/29/20I5. 
Kashua, Sayed. (20I4g). Sayed Kashua is surprised to discover he's white. Haaretz, Jun 5. Available at <http://www. haaretz.com/weekend/weekend/.premium-I.597I43>. Accessed II/29/20I5.

Kashua, Sayed. (20I4h). Why Sayed Kashua is leaving Jerusalem and never coming back. Haaretz, July 4. Available at <http://www.haaretz.com/weekend/weekend/.premium-1.602869>. Accessed I I/29/20I5.

Kimmerling, Baruch. (2008). Crash of identities: explorations in Israeli and Palestinian societies. New York: Columbia University Press.

Kohler-Haunsmann, Issa. (20I I). Discrimination. New York: Oxford University Press.

Lis, Jonathan. (20I4). Knesset passes bill distinguishing between Muslim and Christian Arabs. Haaretz, Feb. 25. Available at <http://www.haaretz.com/news/national/. premium-I.576247>. Accessed I I/29/20I5.

Lughod, Lila A. (I99I). Writing against culture. In: Fox, Richard (Ed.). Recapturing anthropology: working in the present. Santa Fe: School of American Research Press, p. 466-479.

Porat, Chassia Chomsky \& Dakwar, Azar. (20I4). Israeli-Arab literature is part of the nation's canon too. Haaretz, Feb. 27. Available at <http://www.haaretz.com/news/national/. premium-I.576852\#>. Accessed I I/29/20I5.

Prusher, Ilene. (2013). The same Beitar Jerusalem starts a new season with fresh PR paint. Haaretz, Jul. 3I. Available at <http://www.haaretz.com/blogs/jerusalem-vivendi/.premium-I.539037>. Accessed I I/29/20I5.

Rahami, Sawsan. (2010). Israel's discrimination against its Arab citizens. Middle East Monitor, Jun. 29. Available at $<$ https://www.middleeastmonitor.com/resources/briefingpapers/I 230-israels-discrimination-against-its-arab-citizens $>$. Accessed II/29/20I5.

Ravid, Barak. (2010). Lieberman Presents Plans for Population Exchange at UN. Haaretz, Sep. 28. Available at <http://www. haaretz.com/israel-news/lieberman-presents-plans-forpopulation-exchange-at-un-I.3I6I97>. Accessed II/29/20I5. Rekhess, Elie. (2014). The Arab Minority in Israel: Reconsidering the 'I948 Paradigm.' Israel Studies, I9/2, p. I87-217. Avail- 
able at <http://www.dayan.org/kap/images/stories/95597996. pdf $>$. Accessed I I/29/20I5.

Rosenberg, Oz. (2012). Hundreds of Beitar Jerusalem fans beat up Arab workers in mall; no arrests. Haaretz, Mar. 23. Available at <http://www.haaretz.com/print-edition/news/ hundreds-of-beitar-jerusalem-fans-beat-up-arab-workersin-mall-no-arrests-I.420270>. Accessed I I/29/20I5.

Rouhana, Nadim N. (1997). Palestinian citizens in an ethnic Jewish state: identities in conflict. New Haven: Yale University Press.

Sasson-Levy, Orna. (2013). A different kind of whiteness: marking and unmarking of social boundaries in the construction of hegemonic ethnicity. Sociological Forum, 28/I, p. 27-50.

Schiff, Ze'ev. (2007). Self-inflicted injury. Haaretz, Jan. 26. Available at <http://www.haaretz.com/print-edition/opinion/self-inflicted-injury-I.2 I I I89>. Accessed I I/29/20I5.

Schlesinger, Juliana Portenoy. (2009). Autoironia na obra de Sayed Kashua: o tradicional "humor judaico" reaparece em solo israelense. Cadernos de Língua e Literatura Hebraica, 7, p. I93-2I7.

Schlesinger, Juliana Portenoy. (20I I). Languages reveal boundaries of identity in Israel: a bilingual Arabic-Hebrew kindergarten in Jerusalem. Saarbrücken: LAP Lambert Academic Publishing.

Schlesinger, Juliana Portenoy. (20I2). Tão dúbio, tão coerente: forma e conteúdo nas crônicas jornalísticas de Sayed Kashua. Webmosaisa, 4/I, p. IOo-I Io. Available at <http:// www.seer.ufrgs.br/webmosaica/article/view/3IgI I $>$. Accessed II/29/20I5.

Schlesinger, Juliana Portenoy. (2015). Árabe, fale hebraico: a língua como último reduto da batalha identitária do árabe israelense. Cadernos de Língua e Literatura Hebraica, I 2. Available at <http://www.revistas.usp.br/cllh/article/ view/97637/96499>.Accessed I I/29/20I5.

Simon, Luiz Carlos. (20I I). Duas ou três páginas despretensiosas: a crônica, Rubem Braga e outros Cronistas. Londrina: Eduel.

Smooha, Sammy. Still playing by the rules. Index of Arab-Jewish relations in Israel 20I 2: findings and conclusions. Jerusalem: The Israel Democracy Institute/University of Haifa. Available 
at <http://en.idi.org.il/media/2522696/Arab-Jewish-Index20I 2-ENG.pdf $>$. Accessed I I/29/20I5.

Solomon, Ariel Ben. (20I4). Israeli-Arab attitude towards the state remained stable in 2013, study shows. The Jerusalem Post, May 20. Available at <http://www.jpost.com/NationalNews/Israeli-Arab-attitudes-toward-the-state-remainedstable-in-2013-study-shows-352773>. Accessed I I/29/2015. Yelenevskaya, Maria N. \& Fialkova, Larisa. (2004). My poor cousin, my feared enemy: the image of Arabs in personal narratives of former soviets in Israel. Folklore, I I 5/I, p. 77-98. Yiftachel, Oren. (2000). 'Ethnocracy' and its discontents: minorities, protests, and the Israeli polity. Critical Inquiry, 26/4, p. 725-756. 


\section{Palavras-chave \\ Sayed Kashua; \\ Árabe-israelense; \\ Crônica; \\ Discriminação;}

Sociedade israelense.

Keywords

Sayed Kashua;

Israeli Arab;

Columnist;

Discrimination;

Israeli Society.

\section{DESNATURALIZANDO A CULTURA: AS CRÔNICAS DE SAYED KASHUA SOBRE O PRECONCEITO}

Resumo

A discriminação é um tema recorrente na obra do escritor árabe-israelense Sayed Kashua. Nos últimos anos, Sayed Kashua praticamente parou de escrever sobre o preconceito percebido em sua própria comunidade israelense muçulmana e dedicou-se a expressar suas preocupações sobretudo com relação ao preconceito dos judeus contra os árabes em Israel. A auto-crítica sempre foi uma característica da obra de Kashua, e tal fato indica uma mudança na percepção do cronista acerca de sua sociedade. Baseado na abordagem de tópicos sobre a sociedade israelense, tais como a lei, o sistema educacional, e a língua, e na revisão de autores que percebem a alienação mútua de árabes e judeus em Israel, este artigo analisa diversas crônicas recentes de Sayed Kashua publicadas no jornal israelense Haaretz. Investiga também como o cronista compreende o preconceito e, em uma maneira particular e surpreendente, expressa suas preocupações e soluções para o problema.

\section{DENATURALIZING CULTURE: SAYED KASHUA'S NEWS- PAPER COLUMNS ON THE TOPIC OF PREJUDICE}

\section{Abstract}

Discrimination is a recurrent topic in the work of the Israeli-Arab writer Sayed Kashua. In the last couple of years, Sayed Kashua has moved away from writing about the prejudice expressed by his own Israeli Muslim community towards the Israeli Jewish population to focus his attention instead on the prejudice shown by Jews against Arabs in Israel. Self-criticism has always been a hallmark of Sayed Kashua's work so this shift indicates a significant change in the columnist's perception of his own society. Based on a survey of various issues relating to Israeli society, such as the law, the educational system and language, as well as a theoretical review of authors who observe a mutual alienation of Arabs and Jews in Israel, this article analyses several of Sayed Kashua's recent columns in the Israeli newspaper Haaretz. It also investigates how the author understands prejudice and, in a singular and surprising way, expresses his concerns and solutions to this problem. 